\author{
Катерина ОРДУ, \\ orcid.org/0000-0002-4977-1557 \\ аспірантка кафедри педагогіки \\ Південноукраїнського національного педагогічного університету \\ імені К. Д. Уиинського \\ (Oдеса, Україна) kateryna_77@ukr.net
}

\title{
АВТОРСЬКИЙ СПЕЦКУРС \\ «ОСНОВИ ФОРМУВАННЯ ІНФОРМАЦІЙНО-КОМУНІКАТИВНОӤ КОМПЕТЕНТНОСТІ МАЙБУТНІХ СІМЕЙНИХ ЛІКАРІВ»
}

\begin{abstract}
У статті зазначено, щуо інформаційно-комунікативна компетентність сімейного лікаря - ие інтегрована якість особистості, щчо містить сукупність професійних якостей, в основі яких лежать знання, вміння та навички в галузі освоєння нових інформаційних технологій, а також досвіду їх застосування в професійній діяльності; засвоєння фахівцем загальної практики - сімейної медицини правил і норм усної та писемної мови, уміння користуватись ними в лікувально-профілактичному процесі.

Презентовано авторський спецкурс «Основи формування інформаційно-комунікативної компетентності майбутніх сімейних лікарів». Спецкурс призначений для студентів напряму підготовки 222 «Медицина», містить два модулі: Тематичний блок 1. Інформачійно-комунікативна компетентність. Сутність і структура. Особливості фахового мовлення сімейних лікарів. Тематичний блок 2. Інформаційні медичні системи. Інформаційнокомунікаційні технологї в галузі охорони здоров'я. Основи телемедицини. Консультування в умовах пандемії. На вивчення навчальноїдисципліни відводиться 90 годин, 3 кредити Свропейськоїкредитноїтрансферної системи.

Стверджується, щуо основними завданнями вивчення дисципліни «Основи інформаційно-комунікативної компетентності для майбутніх сімейних лікарів» є: опанування теоретичними знаннями шеоо сутності інформаційнокомунікативної компетентності й видів комунікативних моделей поведінки на практичних заняттях; активізація основоположних понять із курсу «Украӥнська мова (за професійним спрямуванням)» $i$ «Медична інформатика»; усвідомлення значущцості державної мови в професійному спілкуванні; опанування основами телемедичного консультування; вдосконалення вмінь і навичок роботи з медичними інформаційними системами Ehealth; вивчення основних принщипів дистаниійного консультування щзодо запобігання інфікування та поширення COVID-19.

Ключові слова: сімейнийлікар, інформаційно-комунікативна компетентність, специкрс, інтегрованенавчання.
\end{abstract}

Kateryna ORDU, orcid.org/0000-0002-4977-1557

Postgraduate Student at the Department of Pedagogy South Ukrainian National Pedagogical University named after K. D. Ushynsky (Odesa, Ukraine) kateryna_77@ukr.net

\section{AUTHOR'S SPECIAL COURSE \\ "FUNDAMENTALS OF FORMATION OF INFORMATION-COMMUNICATIVE COMPETENCE OF FUTURE FAMILY DOCTORS"}

The article states that the information and communication competence of a family doctor is an integrated quality of personality, which includes a set of professional qualities, which are based on knowledge, skills and abilities in the development of new information technologies and experience in their professional activities; mastering by a specialist of general practice -family medicine rules and norms of oral and written language, the ability to use them in the treatment and prevention process.

The author's special course "Fundamentals of formation of information and communicative competence of future family doctors" was presented. The special course is designed for students in the direction of training 222 "Medicine", contains two modules: thematic block 1. Information and communication competence. The essence and structure. Features of professional speech of family doctors. Thematic block 2. Medical information systems. ICT in healthcare. Basics of telemedicine. Pandemic counseling. The study of the discipline is given 90 hours, 3 ECTS credits.

It is stated that the main objectives of the discipline "Fundamentals of information and communication competence for future family doctors" are: mastering theoretical knowledge about the essence of information and communication competence and types of communicative patterns of behavior in practice; activation of basic concepts of the course direction and "Medical Informatics"; awareness of the importance of the state language in professional communication; mastering the basics of telemedicine counseling; improving skills and abilities to work with medical information systems Ehealth; study of the basic principles of remote counseling to prevent infection and spread of COVID-19.

Key words: family doctor, information and communication competence, special course, integrated learning. 
Постановка проблеми. Свропейський курс України передбачає необхідність реформування всіх галузей, зокрема системи охорони здоров'я, 3 метою покращення якості надання послуг пацієнтам і конкурентоспроможності вітчизняних лікарів за кордоном. Останнє можливо за умови набуття ними високого рівня професійної компетентності. Одним зі складників професійної компетентності є інформаційно-комунікативна компетентність, розвиток якої зумовлює здатність лікаря ефективно взаємодіяти в медичному середовищі з колегами, керівництвом, пацієнтами та їх рідними, а також у межах усієї системи охорони здоров'я, що особливо стосується сімейних лікарів, які за фахом взаємодіють із великою кількістю людей.

Зазначимо, що інформаційно-комунікативна компетентність сімейного лікаря - це інтегрована якість особистості, що містить сукупність професійних якостей, в основі яких лежать знання, вміння та навички в галузі освоєння нових інформаційних технологій, а також досвіду їх застосування в професійній діяльності; засвоєння фахівцем загальної практики - сімейної медицини правил і норм усної та писемної мови, уміння користуватись ними в лікувально-профілактичному процесі (Орду, 2019: 189).

Аналіз досліджень. На основі аналізу наукової літератури можна стверджувати, що останнім часом значну кількість досліджень присвячено питанням професійної підготовки майбутніх сімейних лікарів, таким як: формування професійної культури (Наливайко, 2016), педагогічні умови формування професійно-комунікативної культури (Остраус, 2020); формування педагогічної компетентності (Стечак, 2017), формування професійної компетентності (Тітова, 2020) та іншим. 3 огляду на події, спричинені карантинними заходами, вважаємо, що досить актуальним постає питання щодо створення спецкурсу «Основи формування інформаційно-комунікативної компетентності майбутніх сімейних лікарів».

Метою статті $\epsilon$ презентація програми авторського спецкурсу «Основи формування інформаційно-комунікативної компетентності майбутніх сімейних лікарів».

Виклад основного матеріалу. Глобальні зміни, що відбуваються в освіті нині, викликають необхідність інтеграції навчальних дисциплін, яка реалізується на основі інтегрованого й міждисциплінарних підходів.

Необхідно зазначити, що спецкурс - це навчальний курс, який вивчається студентами на старших курсах із метою опанування вузькоспеці- алізованими, новітніми знаннями з певної науки, формування актуальних для певної спеціалізації умінь і навичок (Фіцула, 2006: 146).

Як зазначає учений В. І. Сідоров, головне завдання спецкурсу - мобілізація студентів на поглиблене вивчення окремих тем чи розділів певного курсу (курсів) (Сідоров, 2018: 101).

Інтегрований елективний курс «Основи інформаційно-комунікативної компетентності для майбутніх сімейних лікарів»: а) грунтується на отриманих під час навчання на перших курсах медичних ЗВО базових знань 3 «Української мови (за професійним спрямуванням)» і «Медичної інформатики»; б) продовжує формувати мовну компетенцію, комунікативні навички майбутніх сімейних лікарів; формувати навички щодо роботи 3 інтернет-пристроями й пошуку медичної інформації з використанням інформаційних технологій; в) закладає основи телемедицини 3 перспективою використання здобутих знань у професійній діяльності; г) підвищує рівень комп'ютерної грамотності; грамотності віртуального спілкування; д) ознайомлює студентів зі значенням нових інформаційно-комунікаційних технологій у галузі охорони здоров'я.

Предметом вивчення навчальної дисципліни $\epsilon$ основи сучасного професійного мовлення, медична термінологія, формування навичок і вмінь з інформаційно-комунікативної взаємодії. Міждисциплінарні зв'язки інтегруються 3 дисциплінами гуманітарного спрямування, медичною інформатикою.

Метою викладання навчальної дисципліни «Основи інформаційно-комунікативної компетентності для майбутніх сімейних лікарів» $\epsilon$ формування комунікативних навичок майбутніх сімейних лікарів, ознайомлення студентів зі значенням нових інформаційно-комунікаційних технологій у галузі охорони здоров'я. Основними завданнями вивчення дисципліни «Основи інформаційно-комунікативної компетентності для майбутніх сімейних лікарів» $є$ : опанування теоретичних знань щодо сутності інформаційнокомунікативної компетентності й видів комунікативних моделей поведінки на практичних заняттях; активізація основоположних понять із курсу «Українська мова (за професійним спрямуванням)» і «Медична інформатика»; усвідомлення значущості державної мови в професійному спілкуванні; опанування основ телемедичного консультування; вдосконалення вмінь і навичок роботи 3 медичними інформаційними системами Ehealth; вивчення основних принципів дистанційного консультування щодо запобігання інфікування та поширення COVID-19. 
Результати навчання: опанування студентами мовою на рівні фахового спілкування; наявність стійких знань про специфіку усної та писемної форм української мови в науковому й офіційно-діловому стилях з урахуванням фахової спрямованості; уміння укладати основні види документів; здатність застосовувати знання в практичних ситуаціях.

Студенти повинні знати: термінологію, теоретичні основи й етапи становлення та розвитку нового напряму інтернет-технологій телемедицини; юридичні аспекти телемедицини; переваги дистанційного навчання; концептуальні засади телемедицини; законодавчу базу надання телемедичної допомоги в Україні, порядок оформлення документації; основні принципи організації медичної допомоги хворим із застосуванням телемедичних технологій.

Повинні: застосовувати на практиці методику телемедичного обстеження пацієнта; вести облікову й звітну документацію, надавати звіти про медичну діяльність із застосуванням телемедичних технологій в установленому порядку; проводити телеконсультації в режимах off-line та on-line, відеоконференції; грамотно надавати консультації в телефонному режимі й онлайн.

2. Інформаційний обсяг навчальної дисципліни. На вивчення навчальної дисципліни відводиться 90 годин, 3 кредити Свропейської кредитної трансферної системи. Програма структурована на тематичні блоки й теми.

Тематичний блок 1. Інформаційно-комунікативна компетентність. Сутність і структура. Особливості фахового мовлення сімейних лікарів.

Тематичний блок 2. Інформаційні медичні системи. Інформаційно-комунікативні технології в галузі охорони здоров'я. Основи телемедицини. Консультування в умовах пандемії.

\section{3. Структура навчальної дисципліни} (табл. 1-3).

Таблиця 1

\section{Назви тематичних блоків і тем}

\begin{tabular}{|c|c|c|c|c|c|}
\hline \multicolumn{5}{|c|}{ Кількість годин } \\
\hline \multirow{2}{|c|}{ денна форма } \\
\cline { 2 - 6 } & \multicolumn{5}{|c|}{ тому числі } \\
\cline { 2 - 6 } & Лекції & Практ. & Семінар. & СРС & $\begin{array}{c}\text { Вид } \\
\text { контролю }\end{array}$ \\
\hline
\end{tabular}

Тематичний блок 1. Інформаційно-комунікативна компетентність. Сутність, структура. Особливості фахового мовлення сімейних лікарів.

Тема 1. Сутність понять «комунікація», «компетенція», «компетентність», «інформація», «інформаційно-комунікативна компетентність».

Тема 2. Термінологія в професійному спілкуванні. Специфіка української медичної термінології. Значення комунікації в діяльності сімейного лікаря.

Тема 3. Основні форми комунікативної поведінки сімейного лікаря. Характеристика мовного впливу. Основні поняття мовного впливу: комунікативні невдачі, чинники мовного впливу, комунікативна позиція, способи мовного впливу на особистість. Мовний вплив і маніпулювання. Невербальний і вербальний мовні впливи.

Тема 4. Особливості віртуального спілкування. Норми культури мови. Етикет сімейного лікаря.

Тема 5. Інформаційне суспільство та його особливості. Інформаційні технології. Форми створення та поширення інформації. Пріоритетні напрями розвитку сучасного інформаційного суспільства - завдання охорони здоров'я.

Разом

\begin{tabular}{|l|l|l|l|l|l|}
\hline & & 2 & & $\mathbf{4}$ & Поточний \\
\hline & 2 & & $\mathbf{4}$ & Поточний \\
\hline & 2 & & 4 & Поточний \\
\hline & 2 & & $\mathbf{4}$ & Поточний \\
\hline & 2 & & $\mathbf{4}$ & Поточний \\
\hline & & $\mathbf{1 0}$ & & $\mathbf{2 0}$ & \\
\hline
\end{tabular}

Тематичний блок 2. Інформаційні медичні системи. ІКТ у галузі охорони здоров'я. Основи телемедицини. Консультування в умовах пандемії

\begin{tabular}{|c|c|c|c|}
\hline $\begin{array}{l}\text { Тема 6. Основи телемедицини. Телемедичне консуль- } \\
\text { тування. Підготовка документації. Робота } 3 \text { індивіду- } \\
\text { альними медичними картками. }\end{array}$ & 2 & 4 & Поточний \\
\hline $\begin{array}{l}\text { Тема 7. Історія телемедицини. Телемедицина в Україні. } \\
\text { Одеський обласний центр телемедицини. }\end{array}$ & 2 & 4 & Поточний \\
\hline
\end{tabular}


Орцу К. Авторський спецкурс «Основи формування інформаційно-комунікативної ...

\begin{tabular}{|c|c|c|c|c|}
\hline \multicolumn{5}{|c|}{ Продовження таблиці 1} \\
\hline $\begin{array}{l}\text { Tема 8. Методика телемедичного обстеження, що базу- } \\
\text { ється за принципами телемедичної деонтології. }\end{array}$ & & 2 & 4 & Поточний \\
\hline $\begin{array}{l}\text { Тема 9. Клінічні субдисципліни телемедицини первин- } \\
\text { ної ланки охорони здоров'я. }\end{array}$ & & 2 & 4 & Поточний \\
\hline $\begin{array}{l}\text { Тема 10. Поняття та класифікація баз даних науково- } \\
\text { медичної інформації. Призначення, структура й мож- } \\
\text { ливості довідкових, бібліографічних, реферативних і } \\
\text { фактографічних баз даних. }\end{array}$ & & 2 & 4 & Поточний \\
\hline $\begin{array}{l}\text { Тема 11. Дистанційне навчання. Визначення, мета, } \\
\text { особливості дистанційного навчання. Технології дис- } \\
\text { танційної освіти в медицині. Роль викладача в системі } \\
\text { дистанційної освіти. Контроль знань у медичній освіті. }\end{array}$ & & 2 & 4 & Поточний \\
\hline $\begin{array}{l}\text { Тема 12. Відеоконференція. Вебінар. Вебплатформа. } \\
\text { Онлайн платформи Edmodo та MOODLE. }\end{array}$ & & 2 & 4 & Поточний \\
\hline Тема 13. Спеціалізований сайт сімейного лікаря. & & 2 & 4 & Поточний \\
\hline $\begin{array}{l}\text { Тема 14. Особливості медичної консультації онлайн } \\
\text { і в телефонному режимі. }\end{array}$ & & 2 & 4 & Поточний \\
\hline $\begin{array}{l}\text { Тема 15. Консультування в умовах пандемії: психо- } \\
\text { логічний аспект. Емпатія, толерантність та емоційна } \\
\text { саморегуляція як показники інформаційно-комуніка- } \\
\text { тивної компетентності. }\end{array}$ & & 2 & 4 & Поточний \\
\hline Тема 16. Підсумковий тестовий контроль & & 2 & 4 & Поточний \\
\hline Разом & & 10 & 20 & \\
\hline УСЬОГО & 90 & 30 & 60 & \\
\hline
\end{tabular}

Таблиця 2

Теми практичних занять

\begin{tabular}{|c|c|c|}
\hline $\begin{array}{l}\text { № } \\
\text { 3. II. }\end{array}$ & Тема & $\begin{array}{c}\text { Кіль-ть } \\
\text { Годин }\end{array}$ \\
\hline 1. & $\begin{array}{l}\text { Сутність понять «комунікація», «компетенція», «компетентність», «інформація», «інформа- } \\
\text { ційно-комунікативна компетентність». } \\
\text { Дискусія «Роль інформаційно-комунікативної компетентності в професійній підготовці май- } \\
\text { бутнього сімейного лікаря». }\end{array}$ & 2 \\
\hline 2. & $\begin{array}{l}\text { Термінологія в професійному спілкуванні. Специфіка української медичної термінології. } \\
\text { Значення комунікації в діяльності сімейного лікаря. } \\
\text { Тестовий контроль на грамотність. }\end{array}$ & 2 \\
\hline 3. & $\begin{array}{l}\text { Основні форми комунікативної поведінки сімейного лікаря. Характеристика мовного впливу. } \\
\text { Основні поняття мовного впливу: комунікативні невдачі, чинники мовного впливу, комуніка- } \\
\text { тивна позиція, способи мовного впливу на особистість. Мовний вплив і маніпулювання. Невер- } \\
\text { бальний і вербальний мовні впливи. } \\
\text { Робота в групах. Аналіз комунікативних cumуацій. Call-центрр. }\end{array}$ & 2 \\
\hline 4. & $\begin{array}{l}\text { Особливості віртуального спілкування. Норми культури мови. Чинники дотримання комуні- } \\
\text { кативної норми, встановлення контакту зі співрозмовником, змісту мовлення, мовного оформ- } \\
\text { лення, стилю спілкування, обсягу повідомлення, розташування повідомлення, чинник адресата. } \\
\text { Етикет сімейного лікаря. } \\
\text { Дискусія «Правила віртуального спілкування» }\end{array}$ & 2 \\
\hline 5. & $\begin{array}{l}\text { Інформаційне суспільство та його особливості. Інформаційні технології. Форми створення } \\
\text { та поширення інформації. Пріоритетні напрями розвитку сучасного інформаційного суспіль- } \\
\text { ства - завдання охорони здоров’я. Основні різновиди інформаційних виступів. Правила під- } \\
\text { готовки інформаційних виступів. Дебати «Медична реформа в Україні». }\end{array}$ & 2 \\
\hline 6. & $\begin{array}{l}\text { Основи телемедицини. Визначення телемедицини. Мета, предмет і функції телемедицини. } \\
\text { Телемедична система Medinet. Buступ із презентаціями. }\end{array}$ & 2 \\
\hline 7. & Історія телемедицини. Телемедицина в Україні. Вебквест. & 2 \\
\hline 8. & $\begin{array}{l}\text { Телемедичне консультування. Підготовка документації. Робота з індивідуальними медичними } \\
\text { картками. } \\
\text { Ситуативна вправа «Телемедична консультація». }\end{array}$ & 2 \\
\hline 9. & $\begin{array}{l}\text { Клінічні субдисципліни телемедицини первинної ланки охорони здоров’я. } \\
\text { Тренінг «Телемедичний консиліум». }\end{array}$ & 2 \\
\hline
\end{tabular}




\begin{tabular}{|c|c|c|}
\hline 10 . & $\begin{array}{l}\text { Поняття та класифікація баз даних науково-медичної інформації. Призначення, структура } \\
\text { й можливості довідкових, бібліографічних, реферативних і фактографічних баз даних. Робота } \\
\text { в групах. Cитуативні завдання. }\end{array}$ & 2 \\
\hline 11. & $\begin{array}{l}\text { Дистанційне навчання. Визначення, мета, особливості дистанційного навчання. Технології дис- } \\
\text { танційної освіти в медицині. Відеоконференція. Вебінар. Вебплатформа. Спеціалізований сайт } \\
\text { сімейного лікаря. Роль викладача в системі дистанційної освіти. Контроль знань у медичній } \\
\text { освіті. Практична робота із застосуванням сервісу Google Classroom. }\end{array}$ & 2 \\
\hline 12. & $\begin{array}{l}\text { Консультування в умовах пандемії: психологічний аспект. Емпатія, толерантність та емоційна } \\
\text { саморегуляція як показники інформаційно-комунікативної компетентності. Психологічний } \\
\text { тренінг «Попередження та подолання проявів професійного стресу й синдрому «емоційного } \\
\text { вигорання». Вправа «Асоціації толерантності». Групова дискусія «Які психологічні чинники } \\
\text { можсуть впливати на формування професійної толерантності майбутніх сімейних лікарів?» }\end{array}$ & 2 \\
\hline 13. & $\begin{array}{l}\text { Особливості медичної консультації онлайн і в телефонному режимі. Круглий стіл «Телемеди- } \\
\text { цина в умовах пандемї̈, спричиненої COVID-19». }\end{array}$ & 2 \\
\hline 14. & $\begin{array}{l}\text { Вебекскурсія до Одеського обласного центру телемедицини. } \\
\text { Кейс-стадi. }\end{array}$ & 2 \\
\hline 15. & Підсумковий тестовий контроль. & 2 \\
\hline \multicolumn{2}{|c|}{ Разом } & 30 \\
\hline
\end{tabular}

\section{Самостійна робота}

Таблиця 3

\begin{tabular}{|c|c|c|}
\hline $\begin{array}{l}\text { № } \\
\text { 3/II }\end{array}$ & Назва теми & $\begin{array}{l}\text { Кіль- } \\
\text { кість } \\
\text { годин }\end{array}$ \\
\hline 1. & $\begin{array}{l}\text { Особливості спілкування сімейних лікарів у різних комунікативних ситуаціях. Віртуальна } \\
\text { комунікація. Переклад медичних текстів. }\end{array}$ & 4 \\
\hline 2. & Комунікації в практиці лікаря первинної ланки. Поради щодо спілкування з пацієнтами. & 4 \\
\hline 3. & $\begin{array}{l}\text { Основи роботи системи eНеalth. Призначення системи eHealth. } \\
\text { Медична / госпітальна інформаційна система (MIC / ГІС). }\end{array}$ & 4 \\
\hline 4. & $\begin{array}{l}\text { Відеоконференції: їх види й основні характеристики. Мережеві рішення підтримки відеокон- } \\
\text { ференцій. Багатобічна (багатоточкова) відеоконференція. Програмне забезпечення “Svit" для } \\
\text { проведення багатоточкових відео конференцій. }\end{array}$ & 4 \\
\hline 5. & $\begin{array}{l}\text { Телемедичні проєкти Євросоюзу. AIDMAN - інформаційна система розподіленого доступу до } \\
\text { медичної мережі. C-MONITOR - економічно ефективний персоналізований моніторинг скарг } \\
\text { пацієнтів. HEALTH OPTIMUM - проєкт оптимізації надання медичних послуг за допомогою } \\
\text { засобами телемедицини. }\end{array}$ & 4 \\
\hline 6. & $\begin{array}{l}\text { Застосування ІКТ у медицині, науці й техніці. Підвищення ефективності системи охорони } \\
\text { здоров’я засобами ІКТ. }\end{array}$ & 4 \\
\hline 7. & $\begin{array}{l}\text { Освітні мультимедійні видання та ресурси. Класифікація освітніх мультимедійних видань і } \\
\text { ресурсів. Особливості застосування електронних посібників, віртуальних практикумів, слов- } \\
\text { ників, курсів дистанційного навчання. Бази освітніх ресурсів. }\end{array}$ & 4 \\
\hline 8. & Загальні положення та ресурси України з питань дистанційного навчання. & 4 \\
\hline 9. & Міжнародний досвід в галузі дистанційного навчання. Ресурси Інтернет. & 4 \\
\hline 10 & $\begin{array}{l}\text { Кредитно-модульна (ECTS) програма дистанційного навчання за фахом «Телемедицина й біо- } \\
\text { інженерія». }\end{array}$ & 4 \\
\hline 11 & Програма віртуального інструментарію “LabVIEW”. & 4 \\
\hline 12 & Еволюція “LabVIEW” і загальні відомості про програму. & 4 \\
\hline 13 & Програмування в LabVIEW. & 4 \\
\hline 14 & Медичні додатки. & 4 \\
\hline \multirow[t]{4}{*}{15} & Підготовка до заліку. & 4 \\
\hline & Разом & 60 \\
\hline & Разом СРС $з$ дисципліни, & 56 \\
\hline & у тому числі підготовка до заліку & 4 \\
\hline
\end{tabular}

4. Індивідуальні завдання: написання реферату, доповідь на засіданнях наукових конференцій, підготовка наукової статті, виконання проєктів, створення блогів, персональних сайтів.
5. Оцінювання самостійної роботи студентів. Самостійна робота, яку студент виконує під час підготовки до аудиторного заняття, оцінюється під час поточного контролю теми на відпо- 
відному занятті. Засвоєння тем, які виносяться лише на позааудиторну самостійну роботу, контролюються на підсумковому занятті.

6. Методи навчання. Під час проведення практичних занять використовуються такі методи навчання: діагностування (бесіда, дискусія, спостереження, тестування, творчі роботи); інформування (консультування, розповідь, групове навчання, підсумковий тестовий контроль); самостійна робота (дослідження наукових та інформаційних джерел); практична робота (виконання тренувальних вправ і завдань); операиійний метод (ділові ігри, розв'язання комунікативних ситуацій).

7. Методи контролю: поточна навчальна діяльність студентів контролюється на практичних заняттях відповідно до конкретних цілей i під час індивідуальної роботи викладача зі студентами. Застосовуються такі засоби діагностики рівня підготовки студентів: усне опитування згідно з розробленими викладачем методичними вказівками; блок тестових завдань; самостійна робота; написання есе, рефератів і наукових повідомлень (індивідуальна робота).

8. Поточне оцінювання студентів відбувається на кожному практичному занятті (повинно бути опитано не менше $30 \%$ студентів). Поточна навчальнадіяльністьстудентаоцінюєтьсяза4-бальною (традиційною) шкалою: «5», «4», «3», «2».

9. Засоби контролю знань студентів: тести поточного й підсумкового контролю, збірник ситуативних задач (посібник, електронна бібліотека). Використовуються презентації, дошка, стаціонарні стенди, спеціалізовані підручники, словники й довідники, картки із завданнями.

Висновки. Таким чином, перспективу подальших наукових розвідок убачаємо в розробці навчально-методичного супроводу пропонованого спецкурсу.

\section{СПИСОК ВИКОРИСТАНИХ ДЖЕРЕЛ}

1. Годлевський Л. С., Баязітов М. Р., Мандель О. В., Нєнова О. М., Біднюк К. А, Ляшенко А. В. Телемедичні технології в медицині : навчально-методичний посібник. Одеський національний медичний університет. Одеса, 2020. $356 \mathrm{c}$.

2. Орду К. С. Критерії, компоненти та показники інформаційно-комунікативної компетентності майбутніх сімейних лікарів. Науковий часопис Начіонального педагогічного університету імені М. П. Драгоманова. Серія 5: Педагогічні науки : реалії та перспективи : збірник наукових праць. Київ : Вид-во НПУ імені М. П. Драгоманова, 2019. Вип. 70. С. 189-193. URL: http://enpuir.npu.edu.ua/handle/123456789/27890.

3. Сідоров В. І. Авторський спецкурс «Формування кроскультурної компетентності майбутніх фахівців галузі туризму». Педагогічний часопис Волині. № 1 (8). 2018. С. 101-109.

4. Фіцула М. М. Педагогіка вищої школи : навчальний посібник. Київ : «Академвидав», 2006. 352 с.

\section{REFERENCES}

1. Hodlevs'kyy L. S., Bayazitov M. R., Mandel' O. V., Nyenova O. M., Bidnyuk K. A, Lyashenko A. V. Telemedychni tekhnolohiyi v medytsyni [Telemedicine technologies in medicine. Training manual]. Odesa, 2020. 356 p. [in Ukrainian].

2. Ordu K. S. Kryteriyi, komponenty ta pokaznyky informatsiyno-komunikatyvnoyi kompetentnosti maybutnikh simeynykh likariv [Criteria, components and indicators of information and communication competence of future family doctors]. Scientific journal of the National Pedagogical University named after M.P Drahomanov. Series 5: Pedagogical sciences: realities and prospects: coll. Science. wash. Kyiv: MP Drahomanov National Pedagogical University Publishing House, 2019. Issue 70. pp. 189-193. [in Ukrainian].

3. Sidorov V. I. Avtors'kyy spetskurs «Formuvannya kroskul'turnoyi kompetentnosti maybutnikh fakhivtsiv haluzi turyzmu» [Author's special course «Formation of cross-cultural competence of future specialists in the field of tourism»]. Pedagogical magazine of Volyn. № 1 (8). 2018. pp. 101-109. [in Ukrainian].

4. Fitsula M. M. Pedahohika vyshchoyi shkoly: navch. posibnyk [Pedagogy of higher school: textbook. manual]. Kyiv : Akademvydav, 2006. 352 p. [in Ukrainian]. 